\title{
Fraksinasi dan karakterisasi asap cair dari kayu ulin (Eusideroxylon zwageri Teijsm. \& Binn.) sebagai pelarut kitosan
}

\section{Fractionation and characterization of liquid smoke from ulin wood (Eusideroxylon zwageri Teijsm. \& Binn.) as chitosan solvent}

\author{
Ahmad Budi Junaidi ${ }^{a, b, \star}$, Hayattun Apriyani ${ }^{b}$, Abdullah $^{b}$, Uripto Trisno Santoso ${ }^{b}$ \\ aLaboratorium Biomaterial PS Kimia FMIPA ULM

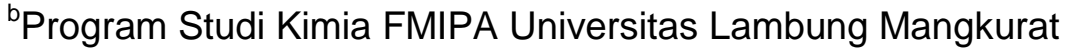 \\ Jl. A Yani Km 36. Banjarbaru Indonesia \\ *E-mail: abjunaidi@ulm.ac.id
}

Diterima 25 Pebruari 2019, Direvisi 05 April 2019, Disetujui 19 Juni 2019

\begin{abstract}
ABSTRAK
Tujuan penelitian ini adalah untuk mempelajari kelarutan kitosan dalam asap cair sebagai kajian awal aplikasi kombinasi kitosan-asap cair sebagai bioimmunizer dan pemacu pertumbuhan pada tanaman. Penelitian fraksinasi dan karakterisasi asap cair dari kayu ulin (Eusideroxylon zwageri Teijsm. \& Binn.) serta uji kemampuannya sebagai pelarut kitosan telah dilakukan. Distilasi fraksinasi dilakukan menggunakan satu set alat distilasi dengan masing-masing fraksi, fraksi $1\left(\leq 100^{\circ} \mathrm{C}\right)$, fraksi $2\left(101-120^{\circ} \mathrm{C}\right)$, dan fraksi 3 $\left(121-140^{\circ} \mathrm{C}\right)$. Asap cair yang dihasilkan kemudian diukur derajat keasaman $(\mathrm{pH})$, analisis total asam, berat jenis, pengujian kelarutan kitosan dalam asap cair dilakukan dengan variasi konsentrasi masing-masing fraksi (1-15\% v/v), dan analisis kadar fenol. Hasil penelitian menunjukkan bahwa nilai rendemen asap cair hasil distilasi fraksinasi masingmasing fraksi berturut-turut adalah 54,91; 29,39; dan 8,8 (\%). Hasil karakterisasi asap cair masing-masing fraksi diperoleh nilai pH fraksi 1, fraksi 2, dan fraksi 3 berturut-turut adalah sebesar 2,33; 2,14; dan 2,08, total asam secara berturut-turut adalah 2,97; 4,59; dan 8,88 $(\% \mathrm{~g} / \mathrm{mL})$, berat jenis berturut-turut adalah 1,005; 1,006; dan 1,009, dan kadar fenol berturut-turut adalah 2,06; 3,67; dan 2,30 (g/L). Kelarutan kitosan di dalam asap cair semakin meningkat seiring dengan besarnya konsentrasi masing-masing fraksi asap cair dan konsentrasi asap cair $5 \%(\mathrm{v} / \mathrm{v})$ sudah mampu melarutkan kitosan lebih dari $50 \mathrm{~g} / \mathrm{L}$.
\end{abstract}

Kata Kunci : kayu ulin, asap cair, distilasi fraksinasi, karakteristik, kelarutan kitosan.

\section{ABSTRACT}

The purpose of this reseach was to study the solubility of chitosan in liquid smoke as a preliminary study of the application of a combination of liquid chitosan as a bioimmunizer and growth booster in plants. Fractionation and characterization of liquid smoke from ulin wood (Eusideroxylon zwageri Teijsm. \& Binn.) and its ability test as chitosan solvent have been performed. Fractional distillation done using a set of tools distillation each fraction, fraction $1\left(\leq 100^{\circ} \mathrm{C}\right)$, the fraction $2\left(101-120^{\circ} \mathrm{C}\right)$, and fraction 3 $\left(121-140^{\circ} \mathrm{C}\right)$. The resulting liquid smoke was then measured degree of acidity, the total acid analysis, the specific gravity, chitosan solubility test in liquid smoke. The result of the research showed that the liquid smoke recovery value of fractionation distillation of each fraction was 54.91; 29.39; and 8.8 (\%). The result of liquid smoke characterization of each fraction obtained $\mathrm{pH}$ value fraction 1 , fraction 2, and fraction 3 are respectively 2.33; 2.14; and 2.08, the total acid was 2.97; 4.59; and $8.88(\% \mathrm{~g} / \mathrm{mL})$, the specific gravity was 1.005; 1.006; and 1.009, and the phenol content was respectively 2.06; 3.67; and 2.30 (g/L). The solubility of chitosan in liquid smoke increasing with the concentration of each liquid 
smoke fraction and 5\% ( $/ \mathrm{v})$ of liquid smoke concentration was able to dissolve chitosan more than $50 \mathrm{~g} / \mathrm{L}$.

Keywords : ulin wood, liquid smoke, fractionation distillation, characteristic, chitosan solvent.

\section{PENDAHULUAN}

Asap cair dan kitosan merupakan bahan alami yang banyak digunakan secara luas pada berbagai bidang industri seperti industri pangan, industri farmasi, dan industri pertanian. Asap cair dapat diperoleh dari pencairan/kondensasi asap hasil pirolisis berbagai biomassa seperti kayu, tempurung kelapa, cangkang sawit, sekam padi, ampas atau serbuk gergaji kayu, dan batang ubi kayu (Darmadji, 2002). Kitosan dapat diperoleh dari hasil deasetilasi kitin yang banyak terkandung dalam cangkang kepiting dan kulit udang (Junaidi, Kartini, \& Rusdiarso, 2010).

Salah satu yang jadi masalah dalam pemanfaatan kitosan adalah kelarutannya yang terbatas. Kitosan umumnya tidak larut dalam air diatas $\mathrm{pH} 6$ karena struktur kristalin yang kaku dan memerlukan asam sebagai donor proton. Kitosan tidak larut dalam basa kuat dan $\mathrm{H}_{2} \mathrm{SO}_{4}$, sedikit larut dalam asam kuat seperti $\mathrm{HCl}, \mathrm{HNO}_{3}$, dan $\mathrm{H}_{3} \mathrm{PO}_{4} 0,5 \%$, akan tetapi kitosan mudah larut dalam asam-asam lemah encer (Zargar, Asghari, \& Dashti, 2015). Asap cair berpotensi menjadi pelarut bagi kitosan karena asap cair mengandung asam karboksilat yang merupakan golongan asam lemah, sehingga kombinasi kitosan dan asap cair dapat dilakukan tanpa menambahkan pelarut bagi kitosan. Penelitian ini bertujuan untuk memberikan data ilmiah tentang tingkat kelarutan kitosan dalam asap cair.

Kombinasi asap cair dan kitosan ini berpotensi untuk dimanfaatkan sebagai agen pemacu pertumbuhan sekaligus proteksi tanaman. Beberapa hasil penelitian telah menunjukkan bahwa kitosan dan asap cair secara terpisah mampu memberi proteksi pada tanaman dari serangan mikroba patogen (EI Hadrami, Adam, El Hadrami, \& Daayf, 2010; Badawy \& Rabea, 2011; Malerba \& Cerana, 2016), meningkatkan pertumbuhan tanaman, improver produksi metabolit sekunder dan aktivator mekanisme pertahanan (Nguyen \& Tran, 2013; Malerba \& Cerana, 2016; Faisal, 2018). Kombinasi kitosan dan asap cair juga berpotensi untuk dimanfaatkan sebagai flavor sekaligus pengawet bahan pangan. Beberapa penelitian menunjukkan bahwa asap cair dapat memberikan cita rasa khas pada makanan olahan (Desniorita \& Maryam, 2015; Berhimpon, Montolalu, Dien, Mentang, \& Meko, 2018). Penelitian lainnya juga menunjukkan bahwa kitosan dan asap cair baik secara terpisah maupun digunakan secara bersama mampu menjadi pengawet bahan pangan (Anggraini \& Yuniningsih, 2013; Saloko, Darmadji, Setiaji, \& Pranoto, 2014; Purba, Suseno, Izaki, \& Muttaqin, 2014; Killay, Nurpudji, Suryani, \& Meta, 2015; Lasindrang, 2017).

Asap cair yang dikaji dalam penelitian ini merupakan hasil kondensasi asap produksi arang kayu ulin yang ada di Desa Ranggang Kecamatan Takisung Kabupaten Tanah Laut. Desa ini merupakan sentra produksi arang kayu terbesar di Kalimantan Selatan untuk memenuhi kebutuhan seluruh wilayah Kalimantan Selatan, bahkan sebagian besar untuk kebutuhan ekspor ke Timur Tengah, Korea, Jepang dan Eropa. Produksi arang kayu daerah ini mencapai 1.500 ton per-bulan. Salah satu bahan dasar yang digunakan dalam produksi arang di Desa Ranggang adalah kayu ulin.Kayu ulin (Eusideroxylon zwageri Teijsm. \& Binn.) termasuk dalam jenis kayu keras, memiliki kepadatan dan struktur kerapatannya yang tinggi dengan berat jenis 1,04 (Abidin, Jauhari, \& Afriza, 2018).

Proses pirolisis asap cair di Desa Ranggang tanpa dilakukan proses pemisahan senyawa tar di dalam pipa kondensor, sehingga asap cair yang dihasilkan masih berwarna hitam. Upaya untuk memisahkan senyawa tar di dalam 
asap cair tersebut dapat dilakukan dengan cara redistilasi, yaitu proses pemisahan kembali suatu larutan berdasarkan titik didihnya (Junaidi, Santoso, \& Abdullah, 2019). Fraksinasi suhu asap cair pada saat redistilasi akan menghasilkan fraksi asap cair yang kemungkinan besar memiliki komposisi, karakter dan kemampuan melarutkan kitosan yang berbeda. Senyawa utama yang terkandung dalam asap pada umumnya ada tiga kelompok, yaitu; senyawa asam organik, senyawa karbonil dan senyawa fenolik. Kelompok senyawa karbonil pada umumnya memiliki titik didih yang rendah (di bawah $100^{\circ} \mathrm{C}$ ), kelompok senyawa asam yang biasanya didominasi asam asetat memiliki titik didih pada kisaran $115-120^{\circ} \mathrm{C}$ dan kelompok senyawa fenolik biasanya memiliki titik didih yang relatif lebih tinggi (Darmadji, 2002).

\section{BAHAN DAN METODE}

Penelitian tingkat kelarutan kitosan dalam masing-masing fraksi asap cair dan karakterisasi asap cair dilaksanakan di Laboratorium Dasar Fakultas MIPA Universitas Lambung Mangkurat Banjarbaru.

\subsection{Alat}

Alat yang digunakan pada penelitian ini diantaranya adalah piknometer, $\mathrm{pH}$ meter, Erlenmeyer, termometer, buret, oven, desikator, vortex shaker, sentrifuse, satu set alat destilasi kaca dengan kapasitas 1 liter dan spektrofotometer UVVis LGS 53 BEL. Photonics.

\subsection{Bahan}

Bahan yang digunakan pada penelitian ini adalah asap cair yang diperoleh dari salah satu tempat produksi arang kayu di Desa Ranggang Kec. Takisung Kab. Tanah Laut, Kalimantan Selatan. Asap yang keluar dari cerobong tungku arang saat proses pirolisis kayu menjadi arang dikondensasi dengan rangkaian pipa besi sehingga diperoleh asap cair grade 3 (Junaidi et al., 2019), kitosan (berat molekul Medium; 200-800 cP; Derajat deasetilasi $80-85 \%$; Sigma-
Aldrich), etanol p.a (99,99\%), $\mathrm{Na}_{2} \mathrm{CO}_{3}$ glasial, pelet $\mathrm{NaOH} 100 \%$ (Merck), reagen Folin-Ciocalteu 10\%, asam galat p.a (Merck), indikator fenolftalein (Merck) dan akuades.

\subsection{Prosedur Kerja Penelitian}

\subsubsection{Distilasi fraksinasi asap cair}

Pemurnian asap cair dilakukan dengan cara distilasi secara fraksinasi. Suhu distilasi yang digunakan pada proses fraksinasi asap cair yaitu suhu $<100^{\circ} \mathrm{C}$, $101-120^{\circ} \mathrm{C}$, dan $121-140^{\circ} \mathrm{C}$. Sebanyak $1 \mathrm{~L}$ asap cair dimasukkan ke dalam labu distilasi, kemudian dipanaskan menggunakan pemanas listrik. Uap yang terbentuk dari hasil distilasi fraksinasi tersebut kemudian masuk ke dalam pipa pendingin (kondensor) dan destilat ditampung dalam sebuah labu. Volume destilat dari masing-masing fraksi yang diperoleh diukur menggunakan gelas ukur.

\subsubsection{Analisis hasil distilasi fraksinasi asap cair}

a. Rendemen masing-masing fraksi

Rendemen masing-masing fraksi diukur berdasarkan volume kondensat yang dihasilkan $(\mathrm{mL})$ dari setiap volume asap cair, rendemennya dapat dihitung menggunakan persamaan sebagai berikut :

Rendemen $(\%)=\frac{\text { Volume kondensat }(\mathrm{mL})}{\text { Volume asap cair }(\mathrm{mL})} \times 100 \%$

b. $\mathrm{pH}$ masing-masing fraksi

Derajat keasaman $(\mathrm{pH})$ sampel masing-masing fraksi asap cair di ukur menggunakan $\mathrm{pH}$ meter. Sampel setiap fraksi asap cair sebanyak $25 \mathrm{~mL}$ diukur, dengan terlebih dahulu dilakukan kalibrasi buffer pada $\mathrm{pH} 4,0$ dan 7,0.

\section{c. Kandungan total asam masing-masing fraksi (AOAC, 2005) \\ Kandungan total asam dari asap cair} dianalisis menggunakan titrasi asam basa. Masing-masing fraksi asap cair diambil sebanyak $10 \mathrm{~mL}$ kemudian diencerkan dengan akuades sampai $100 \mathrm{~mL}$ kemudian diambil lagi sebanyak $10 \mathrm{~mL}$ dan ditambahkan dengan indikator fenolftalein sebanyak 2-3 tetes dan dititrasi dengan 
larutan $\mathrm{NaOH} \quad 0,1 \quad \mathrm{M}$ sampai titik akhir titrasi, yaitu berubahnya warna sampel menjadi merah keunguan dan stabil. Kandungan total asam dinyatakan sebagai persen asam asetat, menggunakan persamaan sebagai berikut:

Total Asam $=\frac{\mathrm{V} \times \mathrm{M} \times \mathrm{BM}}{\mathrm{V}_{\mathrm{c}} \times 1000} \times 10 \times 100 \%$

Keterangan:

$\mathrm{V}=$ Volume titrasi $\mathrm{NaOH}(\mathrm{mL})$

$\mathrm{M}=$ Molaritas $\mathrm{NaOH}$

$\mathrm{BM}=$ Berat Molekul Asam Asetat (60,05 gram $/ \mathrm{mol}$ )

Vc $=$ Volume contoh $(\mathrm{mL})$

\section{d. Berat jenis masing-masing fraksi}

Berat jenis masing-masing fraksi asap cair dianalisis dengan menggunakan alat piknometer. Piknometer dibersihkan terlebih dahulu menggunakan alkohol 96\%, kemudian dikeringkan dan ditimbang. Berat piknometer kosong dicatat sebagai $W_{0}$. Asap cair masing-masing fraksi dimasukkan ke dalam piknometer sampai tanda batas, dan dicatat berat piknometer yang telah berisi sampel sebagai $W_{2}$. Piknometer dibersihkan dengan alkohol 96\% kemudian diisi kembali dengan akuades hingga tanda batas, kemudian didiamkan beberapa saat, ditimbang dan dicatat beratnya sebagai $\mathrm{W}_{1}$ menggunakan persamaan sebagai berikut:

Berat Jenis $=\frac{\mathrm{W}_{2}-\mathrm{W}_{0}}{\mathrm{~W}_{1}-\mathrm{W}_{0}}$

Keterangan:

$\mathrm{W}_{0}=$ Berat piknometer kosong

$\mathrm{W}_{1}=$ Berat air + piknometer

$\mathrm{W}_{2}=$ Berat sampel + piknometer

e. Kadar fenol menggunakan reagen Follin-Ciocalteu (Waterhouse, 2002) Pembuatan larutan induk dan variasi kadar asam galat

Variasi kadar asam galat dibuat dengan menggunakan $10 \mathrm{mg}$ asam galat yang dilarutkan kedalam $10 \mathrm{~mL}$ etanol p.a sehingga didapatkan larutan baku induk 1000 ppm. Kemudian diambil masingmasing sebanyak 0,$1 ; 0,2 ; 0,3 ; 0,4$; dan 0,5 $\mathrm{mL}$ dari larutan tersebut, lalu dimasukkan pada masing-masing labu ukur $10 \mathrm{~mL}$ dan ditambahkan dengan etanol p.a sampai tanda batas. Di peroleh larutan variasi kadar asam galat dengan konsentrasi 10; 20; 30; 40; dan 50 ppm.

\section{f. Penentuan panjang gelombang asam galat}

Larutan standar asam galat $30 \mathrm{ppm}$ diambil sebanyak $0,5 \mathrm{~mL}$, ditambahkan dengan $0,75 \mathrm{~mL}$ reagen Follin-Ciocalteu $10 \%$. Selanjutnya ditambahkan dengan 2 $\mathrm{mL} \mathrm{Na}_{2} \mathrm{CO}_{3} 2 \%$ dan kemudian dikocok dalam vortex shaker. Serapan larutan standar asam galat diukur dengan spektrofotometer UV-Vis pada panjang gelombang maksimum.

\section{g. Pembuatan kurva baku standar asam galat}

Larutan standar asam galat masingmasing konsentrasi $(0 ; 10 ; 20 ; 30 ; 40$; dan 50 ppm) diambil sebanyak $0,5 \mathrm{~mL}$, dimasukkan kedalam tabung reaksi dan ditambahkan dengan $0,75 \mathrm{~mL}$ reagen Follin-Ciocalteu $10 \%$ didiamkan selama 5 menit, ditambahkan dengan $2 \mathrm{~mL} \mathrm{Na}_{2} \mathrm{CO}_{3}$ $2 \%$ dan dikocok dalam vortex shaker kemudian didiamkan selama 18 menit. Pembacaan absorbansi variasi kadar asam galat dengan menggunakan spektrofotometer UV-Vis pada panjang gelombang maksimum.

\section{h. Penentuan kadar fenol masing-masing fraksi}

Sebanyak 0,1 mL asap cair hasil distilasi fraksinasi diambil dari masingmasing fraksi dan dimasukkan ke dalam masing-masing labu ukur $10 \mathrm{~mL}$, diencerkan dengan etanol p.a sampai tanda batas dan diambil $0,5 \mathrm{~mL}$ dari larutan tersebut. Kemudian masing-masing fraksi ditambahkan dengan $0,75 \mathrm{~mL}$ reagen Folin-Ciocalteau 10\% didiamkan selama 5 menit ditambahkan $2 \mathrm{~mL} \mathrm{Na}_{2} \mathrm{CO}_{3} 2 \%$ dan dikocok kemudian didiamkan selama 15 menit. Pembacaan absorbansi kadar fenol dengan menggunakan spektrofotometer UV-Vis pada panjang gelombang maksimum. 
2.3.3. Penyiapan asap cair pada masing-masing fraksi suhu denganvariasi konsentrasi $1 \%$; $2 \%$; $5 \%$; $7,5 \%$; $10 \%$; $12,5 \%$; dan $15 \%$.

Sampel asap cair hasil distilasi fraksinasi diambil sebanyak $1 ; 2 ; 5 ; 7,5 ; 10$; 12,5; dan 15 (mL) pada masing-masing fraksi dengan konsentrasi bervariasi $1 ; 2$; $5 ; 7,5 ; 10 ; 12,5$; dan 15 (\% v/v) dan dimasukkan ke dalam gelas piala $100 \mathrm{~mL}$. Sebanyak $25 \mathrm{~mL}$ asap cair masing-masing fraksi dengan konsentrasi bervariasi diambil kemudian dimasukkan ke dalam gelas piala $50 \mathrm{~mL}$ diukur $\mathrm{pH}$ nya dengan terlebih dahulu dilakukan kalibrasi bufer pada $\mathrm{pH} 4,0$ dan 7,0 .

\subsubsection{Uji kelarutan kitosan dalam masing-masing fraksi asap cair}

Sebanyak 0,5 gram kitosan pada masing-masing fraksi dilarutkan dalam 10 $\mathrm{mL}$ asap cair hasil distilasi fraksinasi variasi konsentrasi $1 ; 2 ; 5 ; 7,5 ; 10 ; 12,5$; dan 15 (\% $\mathrm{v} / \mathrm{v}$ ) dalam gelas piala $50 \mathrm{~mL}$. Kemudian masing-masing campuran dipanaskan dalam water bath pada temperatur $60^{\circ} \mathrm{C}$ selama 30 menit. Selanjutnya campuran disentrifugasi pada kecepatan 1500 rpm selama 20 menit, kemudian masing-masing campuran difiltrasi dan dikeringkan dalam oven pada suhu $100^{\circ} \mathrm{C}$ selama 24 jam sampai beratnya konstan. Persentase kelarutan kitosan ditunjukkan dengan kitosan yang tersisa dibandingkan dengan kitosan sampel berdasarkan persamaan sebagai berikut :

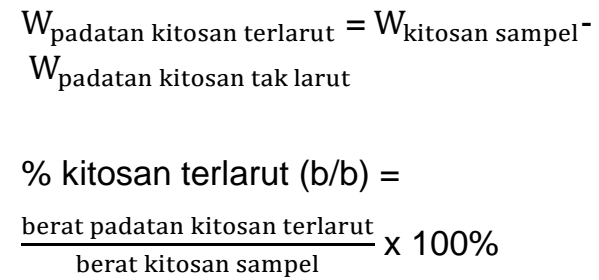

\section{HASIL DAN PEMBAHASAN}

\subsection{Rendemen Distilasi Fraksinasi Asap Cair Kayu Ulin}

Secara visual, asap cair sebelum dan setelah distilasi fraksinasi dapat dilihat pada Gambar 1.

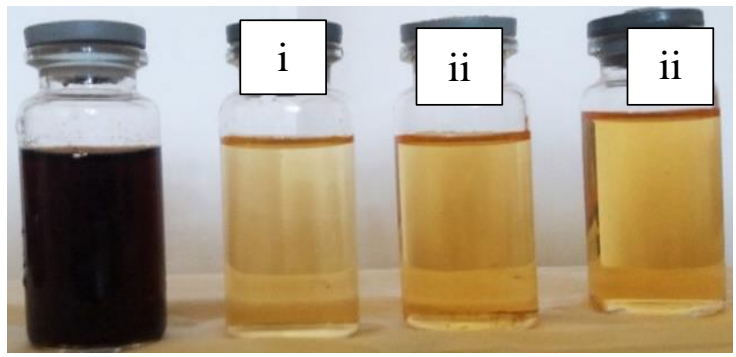

(a)

(b)

Gambar 1. Asap Cair (a) Sebelum Distilasi dan (b) Setelah Distilasi Fraksinasi (i) Fraksi $\leq 100^{\circ} \mathrm{C}$; (ii) Fraksi $101-120^{\circ} \mathrm{C}$; (iii) Fraksi $121-140^{\circ} \mathrm{C}$

Gambar 1 menunjukkan bahwa terjadi perubahan warna dari gambar (a) dan gambar (b). Asap cair sebelum dilakukan distilasi fraksinasi memiliki warna coklat kehitaman yang pekat dan memiliki aroma asap yang menyengat. Sedangkan, asap cair setelah dilakukan distilasi fraksinasi memiliki warna kuning bening pada setiap fraksi. Perubahan warna asap cair dari coklat kehitaman menjadi kuning bening mengindikasikan bahwa komponen senyawa fenolik seperti furfural, asam organik seperti asam asetat, dan karbonil seperti glioksaldehid dalam asap cair telah terpisah dengan senyawa-senyawa fraksi berat seperti poliaromatik hidrokarbon (PAH) dan tar (Lombok, Setiaji, Trisunaryanti, \& Wijaya, 2014; Santoso, 2016).

Rendemen asap cair masing-masing fraksi dari beberapa bahan baku dapat dilihat pada Tabel 1. Berdasarkan Tabel 1 tersebut, asap cair dari kayu ulin menunjukkan bahwa fraksi $1\left(\leq 100^{\circ} \mathrm{C}\right)$ memiliki nilai rendemen yang paling tinggi. 
Tabel 1. Data Rendemen Masing-Masing Fraksi Asap Cair dari Beberapa Bahan Baku

\begin{tabular}{cccc}
\hline \multirow{2}{*}{ Bahan baku } & Suhu & \multicolumn{2}{c}{ Parameter } \\
\cline { 3 - 4 } & pirolisis $\left({ }^{\circ} \mathrm{C}\right)$ & Suhu fraksinasi $\left({ }^{\circ} \mathrm{C}\right)$ & Rendemen $(\%)$ \\
\hline \multirow{2}{*}{ Kayu ulin * } & & $\leq 100$ & 54,91 \\
& - & $101-120$ & 29,39 \\
& & $121-140$ & 8,80 \\
\hline Tempurung kelapa & \multirow{2}{*}{400} & $5 / \mathrm{d} 100$ & 15,72 \\
(Darmadji,2002) & & $100-125$ & 42,11 \\
\hline Tempurung kelapa hibrida & \multirow{2}{*}{400} & $125-150$ & 27,22 \\
(Kadir et al.,2010) & & $100-110$ & 1,60 \\
& & $>110$ & 85,70 \\
\hline
\end{tabular}

Ket: * Data primer yang diolah

Hal ini kemungkinan disebabkan pada suhu $\leq 100^{\circ} \mathrm{C}$ hampir semua kandungan karbonil yang ada pada asap cair tersebut menguap dan banyak kandungan air yang juga ikut menguap menjadi hasil redistilasi (distilat) karena air yang ada dipermukaan larutan dan air yang berinteraksi dengan senyawa yang lebih rendah titik didihnya akan menguap di bawah titik didihnya $\left(\leq 100^{\circ} \mathrm{C}\right)$, sehingga memperbesar rendemen yang diperoleh (Tabel 2).

Tabel 2. Titik Didih Senyawa yang Terkandung dalam Asap Cair (Himawati, 2010)

\begin{tabular}{lc}
\hline Senyawa & $\begin{array}{c}\text { Titik didih } \\
\left({ }^{\circ} \mathrm{C}\right)\end{array}$ \\
\hline Fenolik & 181 \\
Fenol & 211 \\
4-metilguaikol & 162 \\
Furfural & \\
\hline Karbonil & 72 \\
Metilglioksal & 97 \\
Glioksaldehid & 88 \\
Diasetil & \\
\hline Asam & 118 \\
Asam asetat & 141 \\
Asam propionate & 122 \\
Asam Butanoat & \\
\hline
\end{tabular}

Hal ini ditunjukkan bahwa pada titik didih $\leq 100^{\circ} \mathrm{C}$ senyawa yang terkandung dalam asap cair adalah karbonil seperti metal glioksal, diasetil dan glioksaldehid. Berbeda halnya dengan nilai rendemen fraksi $\leq 100^{\circ} \mathrm{C}$ yang diperoleh pada bahan baku tempurung kelapa menunjukkan nilai rendemen yang rendah. Hal ini diduga disebabkan oleh suhu pirolisis dan bahan baku yang berbeda. Senyawa-senyawa karbonil terbentuk dari hasil pirolisis hemiselulosa yang biasanya terjadi pada suhu $200-250^{\circ} \mathrm{C}$ (Darmadji, 2002).

Rendemen hasil redistilasi pada fraksi suhu $\left(101-120^{\circ} \mathrm{C}\right)$ juga memiliki nilai yang cukup tinggi dibandingkan pada fraksi suhu $\left(121-140^{\circ} \mathrm{C}\right)$. Hal ini kemungkinan disebabkan pada suhu $101-120^{\circ} \mathrm{C}$ sebagian besar sisa kandungan air setelah distilasi pada suhu $\leq 100^{\circ} \mathrm{C}$ menguap dan banyak senyawa-senyawa lain seperti asam asetat yang juga ikut menguap berdasarkan titik didihnya pada kisaran suhu tersebut. Asam asetat merupakan komponen asam yang dominan dalam asap cair. Asam asetat terbentuk dari hasil pirolisis selulosa yang biasanya terjadi pada suhu $280-320^{\circ} \mathrm{C}$ (Darmadji, 2002). Walaupun demikian, berdasarkan hasil penelitian Kadir, Darmadji, \& Hidayat, (2010) menyatakan bahwa di dalam asap cair mengandung air hingga $92 \%$.

Asap cair fraksi suhu $121-140^{\circ} \mathrm{C}$ didapatkan nilai rendemen yang sangat rendah, Hal ini mengindikasikan bahwa suhu pirolisis pembentukan asap cair relatif rendah, sehingga hanya sedikit terbentuk senyawa yang memiliki titik didih tinggi (Budaraga, Marlida, Bulanin, \& Arnim, 2017). Pada suhu fraksi di atas $120^{\circ} \mathrm{C}$, komponen yang teruapkan hanya sedikit kemungkinan mengandung air. Kandungan air dalam fraksi di atas $120^{\circ} \mathrm{C}$ dimungkinkan pada air yang berinteraksi cukup kuat dengan senyawa yang memiliki titik didih tinggi. Selain itu, rendahnya 
rendemen hasil redistilasi fraksi $121-140^{\circ} \mathrm{C}$ ini, hanya sedikit senyawa seperti asam butanoat dan asam propionat yang mungkin terbentuk pada proses pirolisis karena asam yang dominan terbentuk adalah asam asetat (Rusdi, 2017) yang titik didihnya di bawah $120^{\circ} \mathrm{C}$.

\subsection{Karakteristik Fraksi Asap Cair Kayu Ulin}

Karakteristik setiap fraksi asap cair yang dianalisis pada penelitian ini meliputi derajat keasaman atau nilai $\mathrm{pH}$, berat jenis, total asam, dan kadar fenol. Hasil analisis karakteristik asap cair hasil distilasi fraksinasi masing-masing fraksi dalam penelitian ini adalah sebagai berikut:

\subsubsection{Penentuan nilai $\mathrm{pH}$ dan total asam asap cair masing-masing fraksi}

Nilai $\mathrm{pH}$ dan total asam asap cair hasil distilasi fraksinasi menunjukkan tingkat proses penguraian komponen senyawa kimia yang terdapat di dalam bahan baku pada saat pirolisis hingga menghasilkan kelompok senyawa asam organik. Senyawa asam organik yang dominan terdapat di dalam asap cair adalah kelompok asam karboksilat terutama asam asetat (Rusdi, 2017). Nilai $\mathrm{pH}$ dan total asam asap cair hasil distilasi fraksinasi dari kayu ulin dan tempurung kelapa dapat dilihat pada Tabel 3 .

Tabel 3. Nilai pH dan Total Asam Asap Cair Kayu Ulin dan Tempurung Kelapa

\begin{tabular}{cccc}
\hline \multirow{2}{*}{ Bahan baku } & \multicolumn{3}{c}{ Parameter } \\
\cline { 2 - 4 } & Suhu fraksinasi $\left({ }^{\circ} \mathrm{C}\right)$ & $\mathrm{pH}$ & Total Asam $(\% \mathrm{~g} / \mathrm{mL})$ \\
\hline \multirow{2}{*}{ Kayu ulin * } & $\leq 100$ & 2,33 & 2,97 \\
& $101-120$ & 2,14 & 4,59 \\
& $121-140$ & 2,08 & 8,88 \\
\hline \multirow{2}{*}{ Tempurung kelapa } & $91-110$ & 1,28 & 1,26 \\
(Rusdi, 2017) & $111-130$ & 1,19 & 2,12 \\
& $131-150$ & 0,94 & 2,87
\end{tabular}

Ket: * Data primer yang diolah

Tabel 4. Nilai Berat Jenis Masing-Masing Fraksi Asap Cair dari Kayu Ulin danTempurung Kelapa

\begin{tabular}{ccc}
\hline \multirow{2}{*}{ Bahan baku } & \multicolumn{2}{c}{ Parameter } \\
\cline { 2 - 3 } & Suhu fraksinasi $\left({ }^{\circ} \mathrm{C}\right)$ & Berat jenis \\
\hline \multirow{2}{*}{ Kayu ulin * } & $\leq 100$ & 1,005 \\
& $101-120$ & 1,006 \\
& $121-140$ & 1,009 \\
\hline Tempurung kelapa (Noor, & $\mathrm{s} / \mathrm{d} 100$ & 1,090 \\
Luditama, \& Pari, 2014) & $100-125$ & 1,100 \\
& $125-150$ & 1,127 \\
\hline Tempurung kelapa (Rusdi, & $91-110$ & 1,011 \\
2017) & $111-130$ & 1,018 \\
& $131-150$ & 1,022 \\
\hline
\end{tabular}

Ket: * Data primer yang diolah 
Berdasarkan Tabel 3, nilai derajat keasaman asap cair pada penelitian ini menunjukkan hasil yang lebih rendah atau nilai $\mathrm{pH}$-nya lebih tinggi jika dibandingkan dengan hasil penelitian Rusdi (2017), namun total asam asap cair yang diperoleh lebih tinggi. Hal ini kemungkinan disebabkan karena asap cair kayu ulin dalam penelitian ini banyak mengandung senyawa asam yang memiliki nilai $\mathrm{Ka}$ (tetapan kesetimbangan asam) yang lebih kecil dibandingkan dengan nilai $\mathrm{Ka}$ senyawa asam yang dominan di dalam asap cair tempurung kelapa. Kemungkinan yang paling besar hal ini disebabkan karena kandungan senyawa fenolik dalam asap cair. Selain senyawa-senyawa asam karboksilat (nilai Ka asam asetat = $1,8 \times 10^{5}$ ), senyawa fenolik juga tergolong asam. Akan tetapi tingkat keasamannya jauh lebih lemah dibandingkan asam karboksilat (nilai $K a$ fenol $=1,3 \times 10^{-10}$ ) (Flowers, Theopold, \& Langley, 2015). Ketika ditentukan total asam asap cair, kontribusi senyawa-senyawa fenolik terhadap total asam berbanding lurus dengan kandungan senyawa fenolik dalam asap cair tersebut. Namun keberadaan senyawa fenolik tidak berkontribusi terhadap nilai $\mathrm{pH}$ asap cair.

\subsubsection{Berat jenis masing-masing fraksi asap cair}

Nilai berat jenis masing-masing fraksi asap cair kayu ulin dan tempurung kelapa dapat dilihat pada Tabel 4. Berdasarkan Tabel 4, nilai berat jenis setiap fraksi asap cair dalam penelitian ini menunjukkan hasil yang sedikit lebih rendah jika dibandingkan dengan hasil penelitian Noor, et al. (2014) dan (Rusdi, 2017). Hal ini kemungkinan disebabkan karena kandungan senyawa asap cair yang diperoleh dari pirolisis kayu ulin dalam penelitian ini banyak mengandung senyawa yang lebih ringan seperti senyawa karbonil. Aplikasi fraksi asap cair dengan berat jenis ringan ini lebih sesuai untuk flavour (Hadanu \& Apituley, 2016; Risfaheri, Hoerudin, \& Syakir, 2018).

Tabel 5. Kadar Fenolik Masing-Masing Fraksi Asap Cair dari Kayu Ulin dan Tempurung Kelapa

\begin{tabular}{cccc}
\hline \multirow{2}{*}{ Bahan baku } & \multicolumn{3}{c}{ Parameter } \\
\cline { 2 - 4 } & Suhu fraksinasi $\left({ }^{\circ} \mathrm{C}\right)$ & Kadar Fenolik $(\mathrm{g} / \mathrm{L})$ & Suhu pirolisis $\left({ }^{\circ} \mathrm{C}\right)$ \\
\hline \multirow{2}{*}{ Kayu ulin * } & $\leq 100$ & 2,06 & - \\
& $101-120$ & 3,67 & \\
\hline Tempurung kelapa & $121-140$ & 2,30 & 400 \\
(Darmadji, 2002) & $100-125$ & 1,64 & \\
\hline
\end{tabular}

Ket: * Data primer yang diolah

Tabel 6. Data pH Hasil Pengenceran Asap Cair

\begin{tabular}{cccc}
\hline \multirow{2}{*}{$\begin{array}{c}\text { Konsentrasi } \\
\text { asap cair }(\%)\end{array}$} & \multicolumn{3}{c}{$\mathrm{pH}$ hasil pengenceran asap cair } \\
\cline { 2 - 4 } & Fraksi 1 $\left(\leq 100 \mathrm{C}^{\circ}\right)$ & Fraksi 2 $\left(101-120^{\circ} \mathrm{C}\right)$ & Fraksi 3 $\left(121-140^{\circ} \mathrm{C}\right)$ \\
\hline 1 & $\mathrm{pH}$ & $\mathrm{pH}$ & $\mathrm{pH}$ \\
2 & 3,64 & 3,48 & 3,29 \\
5 & 3,63 & 3,34 & 3,25 \\
7,5 & 3,47 & 3,23 & 3,22 \\
10 & 3,41 & 3,17 & 3,07 \\
12,5 & 3,36 & 3,12 & 3,01 \\
15 & 3,29 & 3,07 & 2,97 \\
& 3,21 & 2,99 & 2,91 \\
\hline
\end{tabular}


Tabel 7. Hasil Uji ANOVA

\begin{tabular}{lcccc}
\multicolumn{1}{c}{ Sumber Variasi } & Jumlah Kuadrat & $\begin{array}{c}\text { Derajat } \\
\text { Kebebasan }\end{array}$ & $\boldsymbol{F}_{\text {hitung }}$ & $\boldsymbol{F}_{\text {tabel }}$ \\
\hline Konsentrasi asap cair & 0,4490 & 6 & 73,8340 & 2,9961 \\
Jenis fraksi asap cair & 0,3952 & 2 & 194,9554 & 3,8853 \\
Error dalam grup & 0,0122 & 12 & & \\
\hline
\end{tabular}

Tabel 8. Data Tingkat Kelarutan Kitosan Masing-Masing Fraksi pada Suhu $60^{\circ} \mathrm{C}$

\begin{tabular}{|c|c|c|c|c|c|c|}
\hline \multirow{3}{*}{$\begin{array}{c}\text { Konsentrasi asap } \\
\text { cair (\%) }\end{array}$} & \multicolumn{6}{|c|}{ Tingkat kelarutan kitosan masing-masing fraksi suhu } \\
\hline & \multicolumn{2}{|c|}{ Fraksi $1\left(\leq 100 C^{\circ}\right)$} & \multicolumn{2}{|c|}{ Fraksi $2\left(101-120^{\circ} \mathrm{C}\right)$} & \multicolumn{2}{|c|}{ Fraksi $3\left(121-140^{\circ} \mathrm{C}\right)$} \\
\hline & $\begin{array}{c}\text { Kelarutan } \\
(\mathrm{g} / \mathrm{L})\end{array}$ & $\begin{array}{c}\mathrm{pH} \\
\text { larutan }\end{array}$ & $\begin{array}{l}\text { Kelarutan } \\
(\mathrm{g} / \mathrm{L})\end{array}$ & $\begin{array}{c}\mathrm{pH} \\
\text { larutan }\end{array}$ & $\begin{array}{l}\text { Kelarutan } \\
(\mathrm{g} / \mathrm{L})\end{array}$ & $\begin{array}{c}\mathrm{pH} \\
\text { larutan }\end{array}$ \\
\hline 1 & 2,24 & 5,36 & 2,64 & 4,95 & 4,24 & 4,68 \\
\hline 2 & 3,05 & 5,13 & 4,45 & 4,86 & 7,39 & 4,58 \\
\hline 5 & $>50$ & - & $>50$ & - & $>50$ & - \\
\hline 7,5 & $>50$ & - & $>50$ & - & $>50$ & - \\
\hline 10 & $>50$ & - & $>50$ & - & $>50$ & - \\
\hline 12,5 & $>50$ & - & $>50$ & - & $>50$ & - \\
\hline 15 & $>50$ & - & $>50$ & - & $>50$ & - \\
\hline
\end{tabular}

\subsubsection{Kadar fenol}

Berdasarkan Tabel 5 bahwa kadar fenol masing-masing fraksi asap cair kayu ulin yang diperoleh dalam penelitian ini lebih tinggi jika dibandingkan dengan hasil penelitian Darmadji (2002). Hal ini kemungkinan disebabkan pengaruh suhu pirolisis yang digunakan untuk menghasilkan asap cair tersebut. Asap cair kayu ulin yang digunakan dalam penelitian ini merupakan hasil kondensasi asap yang dihasilkan pada proses pirolisis pembuatan arang kayu dengan metode tungku model Desa Ranggang (Junaidi et al., 2019). Menurut Sari et al., (2009) bahwa penguraian lignin menjadi fenolik terjadi pada suhu pirolisis yang tinggi yaitu berkisar antara $400-450^{\circ} \mathrm{C}$. Dengan demikian suhu pirolisis yang terjadi pada pembuatan arang kayu ulin desa Ranggang kemungkinan besar lebih tinggi dari suhu pirolisis tempurung kelapa yang dilakukan Darmadji (2002). Selain suhu pirolisis, senyawa fenolik yang terbentuk dalam asap cair juga dipengaruhi jenis bahan baku yang dipirolisis (Ismail, Runtuwene, \& Fatimah, 2012; K. Budaraga, Arnim, Marlida, \& Bulanin, 2016). Kadar lignin dalam tempurung kelapa sekitar 27\% (Bledzki, Mamuna, \& Volk, 2010), sedangkan dalam kayu ulin sekitar 29\% (Wartawijaya, Kartasujana, Kadir, \& Prawira, 2005).

\subsubsection{Uji kelarutan kitosan dalam masing-masing fraksi asap cair}

Data nilai $\mathrm{pH}$ asap cair masingmasing fraksi dengan konsentrasi yang bervariasi dapat dilihat pada Tabel 6 . Tabel 6 menunjukan bahwa semakin tinggi konsentrasi masing-masing fraksi asap cair maka nilai $\mathrm{pH}$ cenderung semakin turun. Begitu juga jika dibandingkan antar fraksi, semakin tinggi fraksi suhu, $\mathrm{pH}$ asap cair semakih turun. Hasil analisis statistik dengan uji ANOVA 2-faktor (faktor konsentrasi dan faktor jenis fraksi asap cair) dengan tingkat konfidensi 95\% seperti terlihat dalam Tabel 7, menunjukkan bahwa variasi konsentrasi dan fraksi suhu asap cair dapat mempengaruhi $\mathrm{pH}$ secara signifikan. Namun demikian, perubahan konsentrasi yang relatif besar ( $1 \%$ menjadi $15 \%$ ) hanya menurunkan nilai $\mathrm{pH}$ dari 3,64 menjadi 3,21 (untuk fraksi $\leq 100^{\circ} \mathrm{C}$ ); dari 3,48 menjadi 2,99 (untuk fraksi 101$120^{\circ} \mathrm{C}$ ); dari 3,29 menjadi 2,91 (untuk fraksi $121-140^{\circ} \mathrm{C}$ ). Hal ini disebabkan oleh kandungan asam yang terdapat dalam asap cair tersebut adalah asam lemah terutama asam asetat. Asam lemah hanya sedikit melepaskan konsentrasi $\mathrm{H}^{+}$pada 
saat kesetimbangan karena asam lemah memiliki nilai $\mathrm{Ka}$ yang kecil, sehingga $\mathrm{pH}$ yang terukur tidak terlalu berubah walaupun konsentrasi asamnya berubah signifikan.

Berdasarkan Tabel. 8 terlihat bahwa pada konsentrasi (1-2\%) tingkat kelarutan kitosan pada ketiga fraksi asap cair relatif berbeda, semakin tinggi fraksi suhu asap cair semakin tinggi kelarutannya. Hal ini sejalan dengan tingkat keasaman asap cair yang semakin tinggi dengan semakin tingginya suhu fraksi asap cair (seperti terlihat dalam Tabel 6). Data Tabel 6 dan Tabel 8 menggambarkan bahwa tingkat kelarutan kitosan berkaitan erat dengan tingkat keasaman asap cair. Semakin tinggi tingkat keasaman asap cair, semakin besar kemampuannya melarutkan kitosan. Kitosan mudah larut dalam asam lemah encer dengan $\mathrm{pH}$ di bawah 6, biasanya untuk melarutkan kitosan digunakan asam asetat 1\% (Junaidi et al., 2010). Asap cair dapat melarutkan kitosan karena mengandung asam lemah yang didominasi asam asetat. Namun kelarutan kitosan dalam setiap fraksi asap cair pada konsentrasi 1 dan $2 \% \quad(\mathrm{v} / \mathrm{v})$ relative terbatas, walaupun nilai $\mathrm{pH}$ larutan kitosanasap cair masih di bawah 6,0. Hal ini kemungkinan besar disebabkan jumlah asam asetat dalam asap cair yang diencerkan menjadi $1-2 \%$ terlalu sedikit untuk memprotonasi gugus amina kitosan agar dapat larut (Zargar et al., 2015). Sedangkan asap cair setiap fraksi pada konsentrasi $5-15 \%$ sudah mampu melarutkan kitosan lebih dari $50 \mathrm{~g} / \mathrm{L}$. Dengan demikian, asap cair dapat dijadikan sebagai pelarut bagi kitosan untuk kombinasi keduanya dalam aplikasi secara bersama.

\section{KESIMPULAN DAN SARAN}

Kesimpulan yang dapat ditarik yaitu (a) rendemen hasil distilasi fraksinasi asap cair dari kayu ulin hasil kondensasi asap produksi arang kayu desa Ranggang didominasi oleh fraksi suhu $\leq 100^{\circ} \mathrm{C}$; (b) hasil karakterisasi masing-masing fraksi asap cair dari fraksi suhu $\leq 100^{\circ} \mathrm{C}$ fraksi suhu $101-120^{\circ} \mathrm{C}$ dan fraksi suhu 121 - $140^{\circ} \mathrm{C}$ diperoleh nilai derajat keasaman $(\mathrm{pH})$ semakin rendah,total asam $(\% \mathrm{~g} / \mathrm{mL})$ semakin besar, berat jenis relative tidak berbeda sedangkan nilai kadar fenol $(\mathrm{g} / \mathrm{L})$ berturut-turut adalah 2,06; 3,67; dan 2,30; dan (c) kelarutan kitosan berbanding lurus dengan konsentrasi dan fraksi suhu asap cair. Semua fraksi asap cair pada konsentrasi $5 \% \quad(\mathrm{v} / \mathrm{v})$ sudah mampu melarutkan kitosan lebih dari 50 gram/L.

\section{UCAPAN TERIMA KASIH}

Ucapan terima kasih disampaikan kepada Kementerian Riset-Teknologi dan Pendidikan Tinggi yang telah membiayai penelitian ini melalui Hibah PDUPT tahun 2018-2019.

\section{DAFTAR PUSTAKA}

Abidin, Z., Jauhari, A., \& Afriza, M. H. (2018). Kajian potensi dan pengembangan pengusahaan arang kayu di Desa Ranggang Luar Kecamatan Takisung Kabupaten Tanah Laut Provinsi Kalimantan Selatan. Jurnal Hutan Tropis, 6(2), 108-115.

https://doi.org/10.20527/jht.v6i2.5398

Anggraini, S. P., \& Yuniningsih, S. (2013). Liquid smoke purification process for benzo (A) pyrene levels lowering on food safety. Journal of Agriculture and Food Technology, 3(12), 1-4.

AOAC. (2005). Official Methods of Analysis of AOAC International (18th ed.). Washington, DC: Association of official analytical chemists.

Badawy, M., \& Rabea, E. I. (2011). A biopolymer chitosan and its derivatives as promising antimicrobial agents against plant pathogens and their applications in crop protection. International Journal of Carbohydrate Chemistry, 2011, 1-29. https://doi.org/10.1155/2011/460381

Berhimpon, S., Montolalu, R. I., Dien, H. I., Mentang, F., \& Meko, A. U. I. (2018). Concentration and application methods of liquid smoke for exotic smoked Skipjack (Katsuwonus 
pelamis L.). International Food Research Journal, 25(5), 1864-1869.

Bledzki, A. K., Mamuna, A. A., \& Volk, J. (2010). Barley husk and coconut shell reinforced polypropylene composites: The effectof fibre physical, chemical and surface properties. Composites Science and Technology. Vol. 70(2010),pp. 840-846. Composites Science and Technology., 70(5), 840846.

https://doi.org/10.1016/j.compscitech.2 010.01 .022

Budaraga, I. K., Marlida, Y., Bulanin, U., \& Arnim. (2017). Chemical components analysis of Cinnamon liquid smoke with GC MS from various production of different purification method. International Journal of Chemical Technology Research, 10(1), 12-26.

Budaraga, K., Arnim, : Marlida, Y., \& Bulanin, U. (2016). Liquid smoke production quality from raw materials variation and different pyrolysis temperature. International Journal on Advanced Science, Engineering and Information Technology, 6(3), 306. https://doi.org/10.18517/ijaseit.6.3.737

Darmadji, P. (2002). Optimasi pemurnian asap cair dengan metoda redistilasi. Jurnal Teknologi Pangan dan Industri, 13(3), 267-271.

Desniorita, D., \& Maryam, M. (2015). The effect of adding liquid smoke powder to shelf life of sauce. International Journal on Advanced Science, Engineering and Information Technology, $\quad 5(6), \quad 457$. https://doi.org/10.18517/ijaseit.5.6.576

El Hadrami, L R., Adam, I., El Hadrami, \& F. Daayf. (2010). Chitosan in plant protection. Marine Drugs, 8(4), 968987.

https://doi.org/10.3390/md8040968

Faisal, M. (2018). A study on the effectiveness of liquid smoke produced from palm kernel shells in inhibiting black pod disease in cacao fruit in vitro. International Journal of Geomate, 14(43), 36-41. https://doi.org/10.21660/2018.43.3531
Flowers, P., Theopold, K., \& Langley, R. (2015). Chemistry. Houston, Texas: Rice University.

Hadanu, R., \& Apituley, D. A. N. (2016). Volatile compounds detected in coconut shell liquid smoke through pyrolysis at a fractioning temperature of 350-420 celcius. Makara Journal of Science, 20(3), 95-100. https://doi.org/10.7454/mss.v20i3.6239 Himawati. (2010). Pengaruh penambahan asap cair tempurung kelapa destilasi dan redestilasi terhadap sifat kimia, mikrobiologi, dan sensoris ikan pindang layang (decapterus Spp) Selama Penyimpanan. Fakultas Pertanian Universitas Sebelas Maret Surakarta.

Ismail, J., Runtuwene, M. R. J., \& Fatimah, F. (2012). Penentuan total fenolik dan uji aktivitas antioksidan pada biji dan kulit buah Pinang Yaki (areca Vestiaria Giseke). Jurnal IImiah Sains, 12(2), 84-88.

Junaidi, A. B., Kartini, I., \& Rusdiarso, B. (2010). Chitosan preparation with multistage deacetylation of chitin and investigation of its physicochemical properties. Indonesian Journal of Chemistry, 9(3), 369-372. https://doi.org/10.22146/ijc.21500

Junaidi, A. B., Santoso, U. T., \& Abdullah. (2019). Potential of liquid smoke in wood charcoal production of Ranggang Village Tanah Laut Model. Konversi, 8(1), 39-43.

Kadir, S., Darmadji, P., \& Hidayat, C. (2010). Fraksinasi dan identifikasi senyawa volatil pada asap cair tempurung kelapa hibrida. Agritech, 30(2), 57-67.

Killay, A., Nurpudji, A. T., Suryani, A., \& Meta, M. (2015). Chitosan as antimicrobial agent and fatty acid absorber in smoked skipjack tuna processed using coconut shell. American Journal of Life Sciences, 3 (2), 93-99. https://doi.org/10.11648/ j.ajls.20150302.16

Lasindrang, M. (2017). Potential of liquid smoke from palm kernel shell as biopreservative to Tuna (Thumnus sp.) 
fish protein. Indonesian Food and Nutrition Progress, 14(1), 59-67.

Lombok, J. Z., Setiaji, B., Trisunaryanti, W., \& Wijaya, K. (2014). effect of pyrolisis temperature and distillation on character of coconut shell liquid smoke. Proceeding of International Conference On Research, Implementation And Education of Mathematics and Sciences 201, C87C96.

Malerba, M., \& Cerana, R. (2016). Chitosan effects on plant systems. International Journal of Molecular Sciences, 17, 115.

https://doi.org/10.3390/ijms17070996

Nguyen, V. T., \& Tran, T. H. (2013). Application of chitosan solutions for rice production in Vietnam. African Journal of Biotechnology, 12(4), 382384.

https://doi.org/10.5897/AJB12.2884

Noor, E., Luditama, C., \& Pari, G. (2014). Isolasi dan pemurnian asap cair berbahan dasar tempurung dan sabut kelapa secara pirolisis dan distilasi. Prosiding Konferensi Nasional Kelapa VIII, 93-102.

Purba, R., Suseno, S. H., Izaki, A. F., \& Muttaqin, S. (2014). Application of liquid smoke and chitosan as natural preservatives for tofu and meatballs. International Journal of Applied Science and Technology, 4(2), 212217.

Risfaheri, R., Hoerudin, H., \& Syakir, M. (2018). Utilization of rice husk for production of multifunctional liquid smoke. Journal of Advanced Agricultural Technologies, 5 (3), 192197.

https://doi.org/10.18178/joaat.5.3.192197

Rusdi. (2017). Karakteristik asap cair dari tempurung kelapa hasil pirolisis dengan proses distilasi sederhana. Jurnal Pertanian Terpadu, 4(2), 143157.

Saloko, P. Darmadji, B. Setiaji, \& Y. Pranoto. (2014). Antioxidative and antimicrobial activities of liquid smoke nanocapsules using chitosan and maltodextrin and its application on tuna fish preservation. Food Bioscience, 7, 71-79.

Santoso, R. (2016). Characterization of liquid smoke from coconut shell as a natural pesticide for Hexamitodera Semivelutinia Beetle on Clove Trees. International Journal of Applied Chemistry, 12(3), 389-397.

Sari, T. I., Anita, Amalia, \& Rahmawati. (2009). Proses pembuatan asap cair (Liquid Smoke) dari limbah industri. Jurnal Teknik Kimia, 16(2), 44-47.

Wartawijaya, A., Kartasujana, I., Kadir, K., \& Prawira, S. A. (2005). Atlas kayu indonesia (I). Bogor: Pusat Penelitian dan Pengembangan Hasil Hutan.

Waterhouse,. (2002). Determination of total phenolics. in current protocols in food analytical chemistry (Wrolstad R.E., p. I1.1.1-I1.1.4). New York: John Wiley \& Sons, Inc.

Zargar, V., Asghari, M., \& Dashti, A. (2015). A review on chitin and chitosan polymers: structure, chemistry, solubility, derivatives, and applications. chemical and biomolecular engineering, 2(3), 204-226. https://doi.org/cben.201400025. 